\title{
THE USE OF POLYMERASE CHAIN REACTION IN PATIENTS WITH PERIODONTAL DISEASE BEFORE PROSTHETIC TREATMENT
}

\author{
Katarzyna Taraszkiewicz-Sulik', Gabriela Pękała², Łukasz Magnuszewski' ', Maria Gołębiewska' \\ 'Department and Institute of Dental Prosthetics, Medical University in Białystok, Poland \\ ${ }^{2}$ Students' Scientific Association of Dental Prosthetics' Department and Institute of Medical University in Białystok, Poland
}

\begin{abstract}
INTRODUCTION: Periodontal diseases depend heavily on the proliferation of certain pathogenic bacterial species that destroy the periodontium and carry a risk of tissue metastasis. Due to these reasons, the identification as well as assessment of quantity and quality and specific antibiotic therapy of bacterial flora are all crucial in treatment and prevention of the ensuing repercussions of periodontal infections.

Овјестіves: The aim of the study was to evaluate the use of Parodontitis/Periimplantitis-Erreger-Test (PET test) in patients with periodontal diseases in planning the prosthetic treatment.

MATERIAL AND METHODS: We examined 8 patients who had reported the need for filling in dental pockets that were also diagnosed with inflammation of the periodontium. For identifying the periopathogens in a gingival pocket we used the PET test by MIP Pharma.

RESUlts: Despite the removal of dental plaque, a satisfactory state of periodontium was not achieved. After the PET test and the employment of specific antibiotic therapy the state of the periodontium was significantly improved and thus prosthetic fillings were made available. In patients examined after a year there was no observable inflammation in the periodontal region.

ConCLUsions: Microbiological analysis of gingival pockets during periodontal inflammation makes for a good support in diagnostics and prognosis. Despite copious bibliography on the issue and constant development of analytical techniques, using this type of diagnostics in everyday practice is still rare and in need of popularization. The PET test is a perfect tool for identifying the periopathogens and ascertaining the antibiotic therapy needed.
\end{abstract}

KEY wORDs: tooth loss, periodontal diseases, PCR technique.

J Stoma 2018; 71, 3: 273-276

DOI: https://doi.org/10.5114/jos.2018.80646

\section{INTRODUCTION}

There is an enormous amount of bacterial strains in the oral cavity. Dental plaque, associated with the tooth surface, is colonized by a wide range of microorganisms. Periopathogenic bacteria located in subgingival plaque include Porphyromonas gingivalis, Prevotella in- termedia, Campylobacter rectus, Aggregatibacter actinomycetemcomitans, Treponema denticola, and Tannerella forsythensis [1]. During the pathological process of the periodontium a dental pocket is formed, providing a reservoir of bacteria. That causes a direct negative effect in the periodontium but also a high risk of an infectious interaction with remote organs

\section{JOURNAL OF} STOMATOLOGY CZASOPISMO STOMATOLOGICZNE

AdDress for Correspondence: Gabriela Pękała,

3 Akademicka St., 15-267 Białystok, Poland,

phone: +48 731833219, e-mail: gabrielapekala@wp.pl 
and systemic health. There are many publications about the inflammatory process in the periodontium, where bacterial metabolic products and mediators of the immune inflammation reaction can easily pass into the bloodstream (because of the rich vascularity of this area) $[2,3]$.

It is a very complicated and time-consuming process to identify microorganisms with classic methods; therefore there were created commercial sets to determine them. The constant development of diagnostic techniques in bacteriology let to creation of a test which allows one to provide in a short time and without any special techniques qualitative and quantitative components of bacteria in a dental pocket but also an antibiogram - helpful to institute an appropriate treatment plan. The polymerase chain reaction (PCR) technique, connected to molecular probes, is currently one of the methods with the highest sensitivity and specificity in microbiological diagnostics, which has revolutionized present medicine [4-7]. One such test is PET (Parodontitis/Periimplantitis-Erreger-Test), as an additional examination to contribute to the diagnostics and treatment and also to monitor the treatment results in periodontitis and peri-implant tissues. The PET test defines the presence of periodontitis and periimplantitis bacteria, which is based on modern PCR technique. Through polymerase chain reaction many clones of a clearly defined part of a bigger DNA molecule are created. To initiate the reaction the minimal quantity of deoxyribonucleic acid is essential [8-11]. In the PET test a modified PCR technique such as the RT-PCR (real-time PCR) method is used, which enables one to identify the pathogens but also the quantitative assessment and the percentage presence of specific bacteria in subsequent samples. The whole research process is fully automated; therefore the quality and reliability of the test are high. The diagnostic set allows one to perform the procedure in three options: Standard, Plus, Deluxe - depending on clinical needs. The research results are available on- line in approximately three days after the samples are sent to the MIP-Pharma laboratory in Germany. Moreover, the therapeutic recommendations report and bacteriological test results are sent by post. The way of taking the sample and preparing the documentation requires the isolation of the interested area with sterile gauze packs. The sterile paper point is placed in the selected dental pocket and left for about 10-15 seconds. Afterwards, depending on the selected procedure option, the point is placed in an individual or cumulative tube. The next step is to complete the order form, which consists of information about the location and depth of analyzed dental pockets but also information about the patient. This requires giving information about the specific antibiotics that cannot be administered in special cases. Based on the test results the individual antibiotic treatment can be instituted [11].

\section{MATERIAL AND METHODS}

The research included 8 patients ( 5 women and 3 men), who presented themselves at a dental clinic to obtain not only help with bleeding gums but also prosthodontic treatment of the dental pockets. After the anamnesis, an oral examination showed improper condition of the oral cavity tissues which was essential to correct before the proper prosthetic treatment. The examination of the periodontium consisted of: dental pocket depth (PD), clinical attachment level (CAL), sulcus bleeding index (SBI) and approximal plaque index (API). All of the measurements were carried out using a calibrated periodontal probe (WHO). The microbiological assessment of dental pockets uses tests to identify (qualitative and quantitative) 9 bacterial pathogens: Porphyromonas gingivalis (Pg), Prevotella intermedia (Pi), Eikenella corrodens (Ec), Campylobacter rectus (Cr), Actinobacillus actinomycetemcomitans (Aa), Fusobacterium nucleatum (Fn), Tannerella forsythia (Tf), Peptostreptococcus micros (Pm), Treponema denticola (Td). It is based on bacterial DNA in samples obtained with the PCR reaction.

TABLE 1. Clinical parameters in examined patients

\begin{tabular}{|c|c|c|c|c|c|c|c|c|c|}
\hline Patient & $\begin{array}{c}\text { Age } \\
\text { (years) }\end{array}$ & Sex & $\begin{array}{l}\text { Clinical } \\
\text { diagnosis }\end{array}$ & $\begin{array}{l}\text { Mean examined clinical } \\
\text { pocket depth - PD (mm) }\end{array}$ & $\begin{array}{l}\text { Clinical attachment } \\
\text { level - CAL (mm) }\end{array}$ & $\begin{array}{l}\text { SBI } \\
(\%)\end{array}$ & $\begin{array}{l}\text { API } \\
(\%)\end{array}$ & $\begin{array}{l}\text { Number of } \\
\text { remaining teeth }\end{array}$ & $\begin{array}{l}\text { Stimulants } \\
\text { - smoking }\end{array}$ \\
\hline 1 & 53 & W & P.ch. & 4.25 & 4.25 & 100 & 40 & 16 & No \\
\hline 2 & 58 & M & P.ch. & 5 & 5 & 100 & 100 & 6 & No \\
\hline 3 & 54 & W & P.ch. & 4.5 & 4.5 & 100 & 100 & 6 & No \\
\hline 4 & 51 & W & P.ch. & 4.5 & 4.5 & 52.17 & 78 & 26 & No \\
\hline 5 & 43 & W & P.ch. & 3 & 3 & 100 & 81 & 22 & No \\
\hline 6 & 26 & W & P.ch. & 3 & 3 & 100 & 55 & 27 & No \\
\hline 7 & 34 & $M$ & P.ch. & 3.5 & 3.5 & 100 & 19 & 21 & Yes \\
\hline 8 & 35 & $M$ & P.ch. & 3 & 3 & 100 & 71 & 27 & No \\
\hline
\end{tabular}

P.ch. - chronic periodontitis, API - approximal plaque index, SBI - sulcus bleeding index 
TABLE 2. Qualitative and quantitative analysis of bacteria in patients' examined samples

\begin{tabular}{|c|c|c|c|c|c|c|c|c|c|c|c|c|}
\hline \multirow{2}{*}{ Patient } & \multirow{2}{*}{$\begin{array}{c}\text { Age } \\
\text { (years) }\end{array}$} & \multirow{2}{*}{ Sex } & \multirow{2}{*}{$\begin{array}{c}\text { Total } \\
\text { number of } \\
\text { bacteria }\end{array}$} & \multicolumn{3}{|c|}{$\begin{array}{c}\text { Red complex- number of } \\
\text { bacteria }\end{array}$} & \multicolumn{4}{|c|}{ Orange complex- number of bacteria } & \multirow{2}{*}{$\begin{array}{c}\text { A.a. - } \\
\text { number of } \\
\text { bacteria }\end{array}$} & \multirow{2}{*}{$\begin{array}{l}\text { Green complex } \\
\text { C. g. - number } \\
\text { of bacteria }\end{array}$} \\
\hline & & & & P.g. & T.d & T.f. & P.i. & P.m. & F.n. & E.n. & & \\
\hline 1 & 53 & W & $3.3 \times 10^{7}$ & $* 2.6 \times 10^{4}$ & $* 1.1 \times 10^{4}$ & n.d. & *6.1 $610^{4}$ & $8.8 \times 10^{3}$ & $1.2 \times 10^{3}$ & $3.3 \times 10^{2}$ & n.d. & $2.0 \times 10^{4}$ \\
\hline 2 & 58 & M & $2.2 \times 10^{7}$ & $* 5.7 \times 10^{4}$ & $7.2 \times 10^{3}$ & n.d. & ${ }^{*} 2.2 \times 10^{4}$ & $1.3 \times 10^{3}$ & n.d. & $6.0 \times 10^{2}$ & n.d. & $1.4 \times 10^{4}$ \\
\hline 3 & 52 & W & $1.0 \times 10^{7}$ & $* 2.8 \times 10^{4}$ & $2.4 \times 10^{3}$ & $1.4 \times 10^{3}$ & n.d. & $4.0 \times 10^{3}$ & $9.2 \times 10^{3}$ & n.d. & n.d. & $1.3 \times 10^{4}$ \\
\hline 4 & 51 & W & $2.5 \times 10^{7}$ & $2.2 \times 10^{3}$ & n.d. & n.d. & n.d. & $3.5 \times 10^{3}$ & $5.3 \times 10^{3}$ & n.d. & n.d. & $1.7 \times 10^{4}$ \\
\hline 5 & 43 & W & $4.0 \times 10^{6}$ & $* 6.0 \times 10^{4}$ & $1.4 \times 10^{3}$ & $1.3 \times 10^{3}$ & ${ }^{*} 1.7 \times 10^{4}$ & $2.2 \times 10^{3}$ & $1.8 \times 10^{4}$ & n.d. & n.d. & $1.10 \times 10^{4}$ \\
\hline 6 & 26 & W & $2.8 \times 10^{6}$ & n.d. & n.d. & n.d. & $1.2 \times 10^{2}$ & $1.1 \times 10^{2}$ & $1.9 \times 10^{2}$ & n.d. & n.d. & $2.8 \times 10^{3}$ \\
\hline 7 & 34 & M & $3.1 \times 10^{7}$ & n.d. & n.d. & $2.7 \times 10^{3}$ & n.d. & $1.5 \times 10^{4}$ & $3.9 \times 10^{4}$ & n.d. & n.d. & $1.6 \times 10^{2}$ \\
\hline 8 & 35 & $M$ & $5.4 \times 10^{7}$ & $* 1.9 \times 10^{5}$ & n.d. & $6.5 \times 10^{3}$ & $* 4.4 \times 10^{4}$ & $1.8 \times 10^{4}$ & $7.2 \times 10^{4}$ & n.d. & n.d. & $2.9 \times 10^{4}$ \\
\hline
\end{tabular}

P.g. - Porphyromonas gingivalis, T.d. - Treponema denticola, T.f. -Tannerella forsythia, P.i. - Prevotella intermedia, P.m. - Parvimonas micra, F.n. - Fusobacterium nucleatum, A.a. - Aggregatibacter actinomycetemcomitans, E.n. - Eubacterium nodatum, C.g. - Capnocytophaga gingivalis, n.d. - not detected *Treatment essential because of the number or percentage of bacteria.

The research was performed using ready-to-use PET Standard MIP-Pharma tests (MIP-Pharma GmbH, Mühlstraße 50, 66386 St. Ingbert, Germany).

Samples were taken from the 4 deepest dental pockets in patients' teeth. Fifty-eight cumulative tubes (1 cumulative tube for each patient) were obtained. The samples were taken before the hygiene process was performed. After the isolation of the interested tooth and adjacent teeth from the saliva, the supragingival plaque was gently removed using sterile gauze packs. Afterwards, using sterile dental forceps, the paper points were placed for 10 seconds at the bottom of the dental pockets. Removed paper points were put into the special containers (attached to the set) and transported to the laboratory in Germany. The number of saved teeth was evaluated. The correlation between bacteria and clinical index of periodontium condition was assessed.

\section{RESULTS}

The identification of microbiota by PET MIP Pharma tests and aimed antibiotic therapy is crucial for the effective therapy and prevention of complications of infection. Individual antibiotic therapy (local or systemic) established a proper healing process in periodontal tissues. Afterwards the prosthodontic procedure was performed.

During the follow-up visit, a year after the treatment, no symptoms of the inflammatory process in the periodontal area were noted.

\section{DISCUSSION}

In our research 8 people were examined for periodontitis using PET tests to detect periopathogens in dental pockets. The sulcus bleeding index was significant in all the patients. Dental hygiene assessed by the API index was characterized as: bad (100-70\%) in $62.5 \%$ of the examined group, average (69-40\%) in $25 \%$ of the patients, good $(<25 \%)$ in $12.5 \%$. Also CAL and $\mathrm{PD}$ indicated periodontal disease. The PET test results indicated significant numbers of Porphyromonas gingivalis, Treponema denticola and Tannerella forsythia in patients' dental pockets - which helped to diagnose chronic periodontitis. Aggregatibacter actinomycetemcomitans (a marker of aggressive periodontitis) was not detected in any of the patients' samples.

Waśkiewicz [1] examined three female patients, aged 39, 40 and 41. Based on orthopantomographic pictures, she stated that all three patients had moderate periodontitis. Dental pocket depth, measured using a dental probe, in all of the patients was 6-7 $\mathrm{mm}$. To confirm the presence of periopathogens, the PET Standard test was used. Although the clinical symptoms were the same in all three patients, different periopathogens were detected in every patient with the PET Standard test. In the first patient, aged 39, the test confirmed the presence of $A g$ gregatibacter actinomycetemcomitans, which helped to diagnose aggressive periodontitis. In a 40-year-old patient, a significant number of Treponema denticola was observed, which is typical for chronic periodontitis. In the last, 41-year-old patient, no pathogens were noted. Presented case reports show that the same clinical symptoms may have different etiopathogenesis and without the molecular-biologic PET test, appropriate to the causative factor, treatment would not be possible.

Trąbska-Świstelnicka [10] tested ten patients with diagnosed destructive periodontal disease (PET test). She concluded from her research results that clinical symptoms cannot be a sufficient factor to speculate on the alleged bacterial components of subgingival biofilm in periodontal disease, and they cannot be the basis of the antibiotic treatment plan. The antibiotic treatment in periodontitis should be based on the results of molecular-biologic tests. 
Nędzi-Góra et al. [12] used the rival molecularbiologic test Perio-Analyse by Pierre Fabre Medicament. They examined 58 patients; based on anamnesis, intra-oral examination and $\mathrm{X}$-ray photos, severe chronic periodontitis was diagnosed. Subsequent dental pockets were analyzed in terms of qualitative and quantitative assessment of bacteria, and correlations between the bacteria types and between bacteria and the clinical index of periodontal tissue condition in patients with chronic periodontitis were noted.

Czochrowska and Górska [13] stated that in patients wearing fixed orthodontic appliances with diagnosed periodontal disease, it is advisable to evaluate periodontal tissues' condition with molecular-biologic PET tests before as well as during orthodontic treatment.

Kawada et al. [14] obtained very interesting results. They found with the PCR method that along with a $1 \mathrm{~mm}$ increase of the dental pocket's depth the number of Porphyromonas gingivalis rises ten times.

However, Oho et al. [15] first, and also Ciric et al. [16], used saliva samples in their tests. Strużycka et al. [17] also used saliva, but her research was based on two methods. Using polymerase chain reaction in 495 samples, in 91.5\% S. mutans and/or S. sobrinus were observed. However, with the biochemical method using Rapid ID 32 only $39.8 \%$ of pathogens were identified. Her research confirms the precision of molecular-biologic tests.

\section{CONCLUSIONS}

Microbiological tests help to identify the group of patients with high risk of periodontal disease before the first clinical symptoms appear, and to initiate the appropriate treatment plan.

The microbiological analysis of dental pockets in the inflammatory process is helpful in diagnostics and in treatment prognosis.

The PET test is an effective method to indicate the periopathogens and individual antibiotic treatment.

\section{CONFLICT OF INTEREST}

The authors declare no potential conflicts of interest with respect to the research, authorship, and/or publication of this article.

\section{References}

1. Waśkiewicz M. Zastosowanie testu PET standard w praktyce stomatologicznej. Mag Stomatol 2012; 21: 82-87.

2. Kłosińska A, Nowacka M, Kopeć G, et al. Choroby przyzębia a ryzyko chorób sercowo-naczyniowych - przegląd badań epidemiologicznych. Kardiol Pol 2010; 68: 973-976.

3. Spahr A, Klein E, Khuseyinova N, et al. Periodontal infections and coronary heart disease: role of periodontal bacteria and importance of total pathogen burden in the Coronary Event and Periodontal Disease (CORODONT) study. Arch Intern Med 2006; 166: 554-559.
4. Conrads G. DNA probes and primers in dental practice. Clin Infect Dis 2002; 35: 72-77.

5. Jervøe-Storm P, Al Ahdab H, Koltzscher M, et al. Quantification of periodontal pathogens by paper point sampling from the coronal and apical aspect of periodontal lesions by real-time PCR. J Periodontol 2007; 78: 909-917.

6. Osmólska-Bogucka A. Zastosowanie testów diagnostyki mikrobiologicznej u pacjentów z chorobą przyzębia. Nowa Stomatol 2012; 2: 64-68.

7. Teles F, Teles R, Siegelin Y, et al. RNA-oligonucleotide quantification technique (ROQT) for the enumeration of uncultivated bacterial species in subgingival biofilms. Mol Oral Microbiol 2011; 26: 127-139.

8. Pawlik AA. Zastosowanie molekularno-biologicznego testu PET w periodontologii. Opis przypadku. Stomatol Współcz 2011; 18: $34-40$.

9. Salyers AA, Whitt DD. Mikrobiologia. Różnorodność, chorobotwórczość i środowisko. Wydawnictwo Naukowe PWN, Warszawa 2010.

10. Trąbska-Świstelnicka M. Test molekularno-biologiczny PET - do wykorzystania w codziennej praktyce stomatologicznej? Obserwacje własne. Mag Stomatol 2012; 21: 62-68.

11. PET - test na obecność patogenów wywołujących periodontitis/ periimplantitis. Materiały firmowe MIP Pharma Polska Sp. z o.o.

12. Nędzi-Góra M, Kowalski J, Krajewski J, et al. Analiza mikrobiologiczna głębokich kieszonek przyzębnych u osób z przewlekłym zapaleniem przyzębia metodą PCR. Czas Stomatol 2007; 60: 717-725.

13. Czochrowska E, Górska R. Czy leczenie ortodontyczne aparatami stałymi stanowi zagrożenie dla tkanek przyzębia? Nowa Stomatol 2012; 4: 174-179.

14. Kawada M, Yoshida A, Suzuki N, et al. Prevalence of Porphyromonas gingivalis in relation to periodontal status assessed by realtime PCR. Oral Microbiol Immunol 2004; 19: 289-292.

15. Oho T, Yamashita Y, Shimazaki Y, et al. Simple and rapid detection of Streptococcus mutans and Streptococcus sobrinus in human saliva by polymerase chain reaction. Oral Microbiol Immunol 2000; 15: 258-262.

16. Ciric L, Pratten J, Wilson M, et al. Development of a novel multi-triplex qPCR method for the assessment of bacterial community structure in oral populations. Environ Microbiol Rep 2010; 2: 770-774.

17. Strużycka I, Skoczyńska A, Rucińska K. Zastosowanie metody PCR do identyfikacji paciorkowców z grupy mutant. Nowa Stomatol 2001; 3: 15-18. 